\title{
Thanking Expressions in Teaching and Learning Process at English Department of Pasir Pengaraian University
}

\author{
Eripuddin Eripuddin $^{1 *}$, Jufrizal Jufrizal ${ }^{2}$, and Agustina Agustina ${ }^{3}$ \\ ${ }^{1}$ Padang State University, Indonesia \\ ${ }^{2}$ Padang State University, Indonesia \\ ${ }^{3}$ Padang State University, Indonesia \\ *Corresponding author.Email: eripuddin85@gmail.com
}

\begin{abstract}
The purposes of this study were to find out the kinds and the meaning of thanking expressions used by the multiculturalism students. The data was collected from 11 fourth-semester students. This study used descriptive qualitative. The instrument was a discourse completion test (DCT). The result showed there were 110 responses, it divided into 5 kinds of thanking expressions they were 99 responses of thanking (90\%), 6 responses of appreciation $(5,4 \%), 2$ responses of positive feelings $(1,8 \%), 1$ response of apologizing $(0,9 \%)$, and 2 responses of repayment $(1,8 \%)$. This research has examined the kinds and meanings realized by the students. Based on the data, it could be seen that there were different meanings and styles based on their cultural perspective.
\end{abstract}

\section{Keywords: Thanking Expressions, Teaching, Learning Process, Discourse Completion Test}

\section{INTRODUCTION}

A language is a system of communication by using sounds or conventional symbols [1]. It means that English will be used as language communication in daily life. It is through language that we can express ourselves and communicate with others. Furtheremore, English language is important in today's world as it is an international language. According to [2] English become more academic necessaries in human's activities such as education, technology, business, polities, etc. As an international language, there are many aspects that sould be considered in language practice. One of them is the polite expression in communication

Thanking expression is categorized in polite way of communication. This expression is one form of real life of communication that always appears in daily activities. In this case, thank you is one sentence that feels light and sounds simple, but often feels heavy to express in suitable place and time. Even though, this phrase contains their own meaning, which is a high appreciation for those who say and receive these words. There are many reasons to say thank you. Thank you might be expressed to someone for giving a gift, helping, or making a huge impact on his life [3].

Considering of meaning of thanking, there are several cases of using of thanking expression, especially in teaching and learning process at English department of Pasir Pengaraian University. In this case, the researcher saw that students often communicated with others and when they expressed their thanking expression, they did not know what the meaning of the thank you was. They do not understand what the expression of gratitude that is related to language, culture, and context. In addition, they could not use the appropriate expression used in their communication. There were some examples the meaning of thanking expressions found in their communication. Firtsly, thanking expression meant a respect "Thank you for lending us a place". The phrase was spoken in a very polite tone and spoken by people who have been helped the speaker. The second example is thank you meant appear in a greeting at shopping places or other rental places like "let's continue to spend your money here!". In addition, the meaning of thanks can be seen in anothers example such as "Thank you = come please!". The meaning of thanks is the invitation. In short, the meanings of thanking above are directly related to the context used both in written and oral situation.

Seeing the interactions between the students, and among them, there were some lack of understanding about the expressions' patterns and theories of thanking expression; the researcher is interested in conducting a research about the students' thanking expressions in teaching and learning at English Department of Pasir Pengaraian. 


\section{REVIEW OF RELATED LITERATURE 2.1 Language}

According to [4] learning a language is not only relating with the grammar but also the users are able to use it in daily conversation/communication, and are able to describe the sense of the speaker, speakers' intention, and their experiences in various conditions. Furtheremore, language is a very important aspect of human life. So, it should be expressed in impolite way in order to spread the information correctly.

However, there are five components of language [5] such as (1) Phonology is the pattern of the sound in language. 2) Morphology is investigating of the form of the word and the function of the words. 3) Syntax is the study of the pattern of sentences. 4) Semantics is the rules that organize the relationship between language and object, occurrence and relationship of word, along with combination of the word. It can be interpreted as the meaning. 5) Pragmatics is the study about the context and the meaning. Pragmatics also study about how delivery the meaning it does not only rely on the knowledge of linguistics (grammar, lexicon, etc.) from the speaker and the listener, but also from the context of the narrative, knowledge about the status of the parties involved in the conversation, mean implied from the speaker.

Linked the function of the component of language, they give the contribution to the languge used of communication. Furtheremore, the users can inform the message of the communication well, if they have the capablities in spelling, combining the words or sentences correctly, comprehending the pattern of languge and language context

\subsection{Pragmatics}

Pragmatics is covering the study of human language that is related with the context and the society [6]. It means pragmatics study language used and linked with the context. There is the limitation of the pragmatics used in a language. It is the form and the meaning which linked with the speakers' intention, the context/ areas of communication, and the situation. In short, pragmatics are the study of the meaning of speech that is related languages with a context that involves how a speaker produces an words to convey their intentions and how listeners interpret them [7]. It covers several scopes of language such as deixis, implicature, presupposition, and speech acts.

However, pragmatics undertanding will help the speaker in undertanding of language of communication. The speaker can cacth the idea or meaning from the way of communication and the context used of communication. Furtheremore, pragmatics gives the contribution in obtaining the explicit and implicit meaning of language used.

\section{3 Speech acts}

An utterance does not only have an explicit meaning but also an implicit meaning. Speech acts is the act of communication [8]. It is a special role in communication because speech acts that are refered what the speakers' disire or messages should be done by the hearer. In short, the implicit meaning can be known from the actions taken by a person when he/she speaks. It consists of a communication activity (locutionary act) that contains the intention to be conveyed while speaking (illocutionary act) and the effect desired by the speaker (perlocutionary act) [9].

In addition, speech act is the action of the hearer that is caused by the speakers' requesting, commanding, suggesting etc. In this case, mutual understanding is needed in developing a meaning of communication. In others word, meaning of communication can share each others if the hearers understand the context used and the spekers' intention.

\subsection{Thanking Expression}

Thanking expression is a part of speech acts. The part of speech act can be found in the representative of speakers' intention. Furthermore, the expressions of thanking are the mutual relationships between the speakers and the hearers. These expressions appear when the hearers get something or the hearers give the feedback to the speakers. In other words, the actions of thanking expressions are obtained from the relationship between the speakers and hearers [9]. In same way, thanking expression can be meant as the meaning of the part of speech acts such as apology, request, promise etc. In other words, there are some implicit meanings of thanking expressions [10]. Two statements above explained that there was a strategy in expressing thanking expressions and also followed by actions from both the speaker and the listener. Furthermore, thanking expressions are always used to represent the nice thing, because there is a good thing or a benefit one from the previous actions [11]. In addition, thanking expression meant feeling happiness or good sense of the previous [12], [13][14]. However, the others study investigates thanking is a response of receive thing, an expression to refuse the invitation, a response of the services' feedback [15][16][17], an expression of ending the dialog and keeping a good feeling [18].

\section{RESEARCH METHODOLOGY}

The research was descriptive qualitative. However, Descriptive qualitative method is to present a problem or case by presenting the argumentation then following the explanation about the research [19]. Qualitative research covers inviting the participants about their experiences of the case or the problem investigated. It means that there is the interpretation or the result of the research in which is obtained from the combination of researcher's ideas and the participants.

The students' responses are being the data that are obtained by giving discourse completion test (DCT). DCT is a type of language questionnaire where respondents or participants are invited to give the responses toward the descriptions given [20]. In addition, the data of this research is the response of thanking expressions of the participants related the condition given [21]. 
After the data were collected, the data were analyzed by doing some process such as firstly; the researcher read and checked the students' written responses carefully. Secondly, the researcher coded the written responses and determined the kinds of thanking epression used by the students. Then, the researcher analyzed the meaning of thanking expressions had written by the students. Lastly, the researcher explained and presented the result of data that was contained the meaning and kinds of thankin expressions.

The data was analyzed by using formula [22] as follow as:

$$
\begin{gathered}
X=\frac{f}{N} x 100 \% \\
\mathrm{X}=\text { Result } \\
f=\text { Frequency of research result } \\
\mathrm{N}=\text { Total all observe }
\end{gathered}
$$

\section{FINDING AND DISCUSSION}

This study investigated kinds and the meaning of thanking expressions. The result of this study showed that there were 5 kinds of thanking expressions in teaching and learning process at English Department of Pasir Pengaraian University. The data showed that kinds of thanking expressions can be categorized in thanking, appreciation, expressing positive feelings, apology, and expressing repayment.

These expressions were obtained from 110 responses that indicated 5 kinds of thanking expressions such as: ninety nine responses meant thanking (90\%), six responses represented appreciation $(5,4 \%)$, two responses described positive feelings $(1,8 \%)$, one response meant apology $(0,9 \%)$ and two responses meant expressing repayment $(1,8 \%)$. So, there were the different used of thanking expression in a different context in teaching and learning activities.

The results showed that there are the different meanings of thanking expressions. Furthermore, they did not care the situation or the context. It meant that most of the students did not understand the appropriate expressions and responses of thanking. In others hand, thanking expression meant the appreciation of doing something thing or the feedback doing something. Furthermore, the data showed that there were some

\begin{tabular}{|c|c|c|c|}
\hline No & $\begin{array}{c}\text { Kinds of } \\
\text { Thanking } \\
\text { Expressions }\end{array}$ & Number & Percentage \\
\hline 1 & Thanking & 99 & $90 \%$ \\
\hline 2 & Appreciation & 6 & $5,4 \%$ \\
\hline 3 & Positive Feelings & 2 & $1,8 \%$ \\
\hline 4 & Apology & 1 & $0,9 \%$ \\
\hline 5 & Repayment & 2 & $1,8 \%$ \\
\hline & Total & 110 & $100 \%$ \\
\hline
\end{tabular}
meanings of thanking expression as follows the table 1 .

Table 1. The Data Findings of the Kinds of Thanking Expressions used by the Students.

Based on the result of research, there were some cases found in using of thanking expressions. They could be found in the situation presented from situation 1 up to situation 10 as follows:

Table 2. Situation 1.

You come to the class, say greeting to your friend and seating near the front of the lecturers' table. At the same time, you ask your friend to take your chair. You seat to the front, and your friend takes it and gives it.

\begin{tabular}{|c|l|c|l|c|}
\hline \multicolumn{5}{|c|}{ Student's Responses } \\
\hline \multicolumn{1}{|c|}{ No } & \multicolumn{1}{|c|}{ Responses } & Freq. & $\begin{array}{c}\text { Kinds of Thanking } \\
\text { Expressions }\end{array}$ & Percentage \\
\hline 1 & Thank you & 7 & Thanking & $63,6 \%$ \\
\hline 2 & Thank you for responding & 1 & Thanking & $9,1 \%$ \\
\hline 3 & I greatly appreciate your help & 3 & Expressing appreciation & $27,3 \%$ \\
\hline \multicolumn{4}{|c|}{ Total } & \multicolumn{2}{c|}{$100 \%$} \\
\hline
\end{tabular}

Situation 1 was familiar to the condition of the students' classroom. Of course, the classroom was one of the most popular academic conversations. It was clear that this condition was a formal area and it could be said there was relationship between students and the lecturers. For this reason, the students gave simple responses to show the expressions of thanking. The students used the appropriate of thanking expression meanwhile there were others way of thanking expressions.
Linked to thanking expression, there were others case of the appropriate of thanking expression such as in the situation 2 showed that most of students used simple thanking in giving a response. It could be seen that the situation was formal, then the kinds of thanking expressions suitable for responding of the situation, it was "thanking" and followed by expressing appreciation, for example "Thank you so much, sir. I really appreciate it." 
Table 3. Situation 2

\begin{tabular}{|c|c|c|c|c|}
\hline \multicolumn{5}{|c|}{ Student's answer of thanking } \\
\hline No & Answers & Freq. & $\begin{array}{c}\text { Kinds of Thanking } \\
\text { Expressions }\end{array}$ & Percentage \\
\hline 1 & Thank you very much & 7 & Thanking & $63,6 \%$ \\
\hline 2 & Thank you for your appreciation & 3 & Thanking & $27,3 \%$ \\
\hline 3 & $\begin{array}{l}\text { Thank you very much for your } \\
\text { appreciation }\end{array}$ & 1 & Thanking & $9,1 \%$ \\
\hline
\end{tabular}

The other cases of the using of thanking expression could be seen the situation 3. It generally happens in the public area and informal situation. For example, this situation happened in a supermarket. Therefore, most of the students used thanking in responses the situation. The data showed that the student was familiar with the expression of "Thank". Based on the explanations above, it could be seen that the situation was an informal situation, then the kinds of thanking expressions suitable for responding to the situation was the kind of "thanking" for example, "thank you for your help."

Table 4. Situation 3

\begin{tabular}{|c|c|c|c|c|}
\hline \multicolumn{5}{|c|}{$\begin{array}{l}\text { At classroom, you tell to your friend to bring your bag. She agrees about this and then she } \\
\text { comes back to the class again. Then she takes your bag and brings it to your places. }\end{array}$} \\
\hline \multicolumn{5}{|c|}{ Student's answer } \\
\hline No & Answers & Freq. & $\begin{array}{l}\text { Kinds of Thanking } \\
\text { Expressions }\end{array}$ & Percentage \\
\hline 1 & Thanks & 7 & Thanking & $63,6 \%$ \\
\hline 2 & Thank you for help & 3 & Thanking & $27,3 \%$ \\
\hline 3 & Thank you for the service & 1 & Thanking & $9,1 \%$ \\
\hline \multicolumn{4}{|c|}{ Total } & $100 \%$ \\
\hline
\end{tabular}

Table 5. Situation 4 (Male and Female)

On the table in the class room, there is a dirty thing on your clothes and your friend takes it. You keep smile and say something good

\begin{tabular}{|c|l|c|l|c|}
\hline \multicolumn{1}{|c|}{ Answers } & Freq. & Kinds of Thanking Expressions & Percentage \\
\hline No & \multicolumn{1}{|c|}{ Thanks } & 2 & Thanking & $18,2 \%$ \\
\hline 2 & Thank you & 1 & Thanking & $9,1 \%$ \\
\hline 3 & Thanks for your nice help & 1 & Thanking & $9,1 \%$ \\
\hline 4 & Thank you for your help & 1 & Thanking & $9,1 \%$ \\
\hline 5 & Thank you so much & 5 & Thanking & $45,5 \%$ \\
\hline 6 & Thank you for your care & 1 & Thanking & $9,1 \%$ \\
\hline \multicolumn{2}{|l}{ Total } & $100 \%$ \\
\hline
\end{tabular}

The situation 4 showed that it is not a sincere thank you with extra expression and the recipient might not really accept the expressions of caring by her friend. So, because of the situation were the informal situation and the close relationship between two friends, the suitable kinds of thanking expressions for responding to the situation was "thanking" that was followed by apology like, "thanks dear, it is do embarrassing if you do not tell me". 
Table 6. Situation 5.

In the end of semester, You must pay your semester cost. You do not have money. You talk to your friend. Your friend borrow the money by using the check.

\begin{tabular}{|c|l|c|l|c|}
\hline \multicolumn{5}{|c|}{ Student's answer } \\
\hline No & \multicolumn{1}{|c|}{ Answers } & Freq. & \multicolumn{1}{|c|}{ Kinds of Thanking } & Percentage \\
\hline 1 & Thank you & 1 & Thanking & $9,1 \%$ \\
\hline 2 & Thank you for help & 7 & Thanking & $63,6 \%$ \\
\hline 3 & Thank you for your great help & 1 & Thanking & $9,1 \%$ \\
\hline 4 & I greatly appreciate your help & 1 & Expressing appreciation & $9,1 \%$ \\
\hline 5 & I am so grateful for your help & 1 & Expressing positive feelings & $9,1 \%$ \\
\hline \multicolumn{4}{|c|}{ Total } & $100 \%$ \\
\hline
\end{tabular}

The data from table $\mathbf{6}$ situation 5 showed that the most of the students used thanking (thank you, thank you for help, thank you for your great help). Therefore, it can be seen that the situation was an informal situation. So, the appropriate kinds of thanking expressions for responding to the situation was "thanking" that was followed by expressing positive feelings and repayment suc as "thanks friend, I am so grateful for your help. I will pay back as soon as possible".

Table 7. Situation 6.

You learn Drama subject. At the time your group are going to present the paper of your topic. But You do not come on time because your house is far from the campus then your members of your group have presented your papers.

\section{Student's answer}

\begin{tabular}{|c|l|c|l|c|}
\hline No & \multicolumn{1}{|c|}{ Answers } & Freq. & \multicolumn{1}{|c|}{$\begin{array}{c}\text { Kinds of Thanking } \\
\text { Expressions }\end{array}$} & Percentage \\
\hline 1 & Thank you for help & 6 & Thanking & $54,5 \%$ \\
\hline 2 & Thank you very much & 3 & Thanking & $27,3 \%$ \\
\hline 3 & I am sorry for coming late & 1 & Apologizing & $9,1 \%$ \\
\hline 4 & Thank you for your help, next time I will come on time & 1 & Thanking + Repayment & $9,1 \%$ \\
\hline \multicolumn{2}{|c|}{ Total } & $100 \%$ \\
\hline
\end{tabular}

The situation 6 showed informal situation where there were the conversation between students and their classmates. It can be seen that most of the students used 'thanking' that was followed by stating the reason 'thank you for help'. Based on the explanations above, it could be seen that the situation was informal. So, the appropriate of thanking expressions for responding to the situation was "apologizing" that was followed by expressing repayment for example, "I am so sorry that I did not keep my promise. Next time I will do it".

Table 8. Situation 7.

In classroom break time, your friend advices to get out to have lunch. But You do not care about that because you do not have enough money, and your friend know about yours. He said "I will pay You, don't matter about the money". Then you go to the restaurant happily.

\begin{tabular}{|c|l|c|l|c|}
\hline \multicolumn{2}{|c|}{ Answers } & \multicolumn{1}{|c|}{ Student's answer } \\
\hline No & \multicolumn{1}{|c|}{$\begin{array}{c}\text { Kreq. } \\
\text { Expressions }\end{array}$} & Percentage \\
\hline 1 & Thanks & 1 & Thanking & $9,1 \%$ \\
\hline 2 & Thank you very much & 6 & Thanking & $54,5 \%$ \\
\hline 3 & I owe you one & 1 & Expressing repayment & $9,1 \%$ \\
\hline 4 & I greatly appreciate your help & 1 & Expressing appreciation & $9,1 \%$ \\
\hline 5 & $\begin{array}{l}\text { Thank you for the food, I hope your } \\
\text { fortune increases }\end{array}$ & 1 & $\begin{array}{l}\text { Thanking + Expressing } \\
\text { positive feelings }\end{array}$ & $9,1 \%$ \\
\hline 6 & Thank you so much for your treating friend & 1 & Thanking & $9,1 \%$ \\
\hline
\end{tabular}


The sitaution above is the usual habit of our culture, paying the lunch is a the good thing. So in this sentence, the student said thank you for being treated by his friend. Based on the explanations above, it can be seen that the situation 7 was informal and the context was friend's generosity. In this case, ordering the lunch to our friend is the usual thing in our culture. At the same time, automatically, we will say the expression of thanking and this expression symbolize our deep feeling of receiving someting. So, the suitable of thanking expressions for responding was "thanking" that was followed by expressing repayment such as, "Thanks for lunch today, next time my turn to treat you".

Table 9. Situation 8.

In one conversation in the class. You perfom the new style of your. It is your favorite one. Your classmate feels something different with you and he said "are you there?

There is some thing cool

\begin{tabular}{|c|l|c|l|c|}
\hline \multicolumn{5}{|c|}{ Student's answer } \\
\hline No & \multicolumn{1}{|c|}{ Answers } & Freq. & $\begin{array}{c}\text { Kinds of Thanking } \\
\text { Expressions }\end{array}$ & Percentage \\
\hline 1 & Thank you & 4 & Thanking & $36,4 \%$ \\
\hline 2 & Thank you very much & 1 & Thanking & $9,1 \%$ \\
\hline 3 & Thank you for the compliment & 1 & Thanking & $9,1 \%$ \\
\hline 4 & Thank you for your praise & 5 & Thanking & $45,5 \%$ \\
\hline \multicolumn{2}{|c|}{ Total }
\end{tabular}

In situation 8 , the context of this situation was a compliment expressing. The data showed that there were 4 students used 'thank you' and 5 students used the expression 'thank you for your praise'. It was clear that there were the differents used of thanking expression because they assumed that this response of thanking followed that had a meaning a stating the favor. In this case, these responses were not only means as expressed grateful for the compliment but also it could meant as a mocked. It was caused by the different cultrures and the differents understanding about thanking expression used.

Based on the explanations above, it could be seen that the situation was informal situation and the context was close relationship. So, the kind of thanking expressions used was "thanking" like "Thank you".

Table 10. Situation 9.

\begin{tabular}{|c|c|c|c|c|}
\hline \multirow{2}{*}{\multicolumn{5}{|c|}{$\begin{array}{l}\text { Out the class, You share the slide of your presentation to you } \\
\text { debating the topic. You ask your leturer to hand you explaini } \\
\text { more understanding. }\end{array}$}} \\
\hline & & & & \\
\hline No & Answers & Freq. & $\begin{array}{l}\text { Kinds of Thanking } \\
\text { Expressions }\end{array}$ & Percentage \\
\hline 1 & Thanks & 1 & Thanking & $9,1 \%$ \\
\hline 2 & Thank you & 1 & Thanking & $9,1 \%$ \\
\hline 3 & Thank you so much & 3 & Thanking & $27,3 \%$ \\
\hline 4 & Thank you for your help & 6 & Thanking & $54,5 \%$ \\
\hline
\end{tabular}

The situation 9 showed that the context of the conversation was formal, the students don not give appropriate expression of thanking and make it the condition unseroiusly. It can be seen that the expression " thank you for your help " is not suitable with the condition. The most of the students used 'thank you for

your help' to response the expression. Meanwhile the context used was two friends that had the close relationship. So, the appropriate of thanking expressions for responding it was "thanking" like the expression "Thanks, sir.". 
Table 11. Situation 10.

In the end of the class, the lecturer closes the class and gives the some home works for next meeting. But, he
leave the class, he shares and explains what should do for the homework.
\begin{tabular}{|c|l|c|c|c|}
\hline \multicolumn{2}{|c|}{ Answers } & Freq. & $\begin{array}{c}\text { Kinds of Thanking } \\
\text { Expressions }\end{array}$ & Percentage \\
\hline \multirow{2}{*}{ No } & & 4 & Thanking & $36,4 \%$ \\
\hline 1 & Thank you & 5 & Thanking & $45,5 \%$ \\
\hline 2 & Thank you for help & 1 & Thanking & $9,1 \%$ \\
\hline 3 & Thank you so much for your help & 1 & Expressing appreciation & $9,1 \%$ \\
\hline 4 & I appreciate it! & $100 \%$ \\
\hline \multicolumn{2}{|c|}{ Total } \\
\hline
\end{tabular}

In situation 10, most of the students say thanking when they get the explanation more from the lecturers. There are 4 students give the response about the condition above with the phrase "thank you". Then there are 5 students response "Thank you for help". This data is indicated that the students don not understand how to express thanking in a conversation well. Based on the explanations above, it can be seen that the situation is in a formal situation, then the kinds of thanking expressions for responding to the situation was "thanking" like the expression "Thank you, sir.".

Generally, the result of this research showed that the most of students used simple thanking expressions in giving a response. Furthermore, different expression may be caused by the multicultural and misunderstanding about the context used $[23][24][25]$. The different of thanking epressions used were influenced by the students' social background and their cultures [26]. However, formal situations occurred when talking to people who have a higher position than the speakers. As for informal situations, this usually happens between the speakers and hearers who had the same age and the social status [27][28][29]. So, there were the appropriate expression used in a formal and non formal contexts.

\section{CONCLUSION}

There were the different kinds and meaning of thanking expressions used by the students. The different context gave the influence to thanking expression in studying process. There were some meaning of thanking found such as thanking itself, the good feedback, the praise word/response, the refused word and repayment staement. Furthermore, the different of meaning of thanking were caused by the social background, context and gender. In short, it could be argued that the multicultural context provide the different responses of thanking in teaching and learning process.

\section{REFERENCES}

[1] Austin, J. L. (1962). How To Do Things With World. London: Oxford University Press.

[2] Eisenstein, M. \& Bodman, J. W. (1986). "I very appreciate": Expressions of gratitude by native and nonnative speakers of American English. Applied Linguistics, 7, 167185.http://d.doi.org/10.1093/applin/7.

[3] Eisenstein, M. \& Bodman, J. W. (1993). Expressing gratitude in American English. In G.Kasper \& S. Blum-Kulka (Eds.), Interlanguagepragmatics (pp.64-81). New York: Oxford University Press.

[4] Farnia, M., \& Suleiman, R. (2009). An interlanguage pragmatic study of expressions of gratitude by Iranian EFL learners-A pilot study. Malaysian Journal of ELT Research, 5, 108-140.

[5] Feng Kong, Jingjing Zhao, Xuqun You. (2019). Gratitude and The Brain: Trait Gratitude Mediates The Association Between Structural Variations in The Medical Prefrontal Cortex and Life Satisfaction. American Psychological Association, 10.1037, 1-10.

[6] Filpisan, M; Tomuletiu, A; Gyorgy, M; \& Moldovana, T. (2012). Practical Guide of Intercutural Education. Procedia, Social and Behavioral Science, 46, 5528-5532.

[7] Fishghadam, R. \& Zarei, S. (2011). Expressions of gratitude: A case of EFL learners. Review of European Studies, 3, 2.

[8] Fozdara, F. \& Volet, S. (2012). Intercultural Learning Among Community Development Students : Positive Attitudes, Ambivalent Experiences. Routledge, 43, 3, 361-178.

[9] Fraenkel, J.R., dan Wallen, N.E. (2007). How to Design and Evaluate Research in Education. Boston: McGraw Hill.

[10] Gardner, H. (1983). Frames of mind: The theory of multiple intelligences. New York: Basic Books. [3] C. Baier, J-P. Katoen, Principles of Model Checking, MIT Press, 2008.

[11]Gardner, H. (1993). Multiple intelligences: The theory in practice. New York: Basic Books.

[12] Gass,S.M and New. J (2006). Speech Act Across Cultures. Chalenges to Communication in a Second Language. Berlin: Walterde Gruyter.

[13] Gay, L.R., Mills, G.E., and Airasian, P. (2009). Educational Research: Competencies for Analysis and Application. Columbus: Pearson. 
[14] George, Michailidis \& Aikaterini MaridakiKassotaki. (2020). Reliability and Construct Validity of The Greek Gratitude Questionnaire (GQ6) in A Sampleof Children Aged 11 to 12 Years. Obrela Journal, 3, 56-62

[15] Gila A. Schauer, Svenja Adolphs. (2005). Expressions of Gratitude in Corpus and DCT Data: Vocabulary, Formulaic Sequences, and Pedagogy. Elsivier, 10.1016, 1, 119-134.

[16] Giskin Day. (2019). Enhancing Relational Care through Expressions of Gratitude: Insights from A Historical Case Study of AlmonerPatient Correspondence. Med Humanities, 10.1136, 1-11

[17] Gomez, M.Elena \& Parra. (2020). Measuring Intercultural Learning through CLIL. Journal of New Approaches in Educational Research, 9, 1, 43-56.

[18] Green, G. (1989). Pragmatics and Natural Language Understanding. Mahwah,N. I.: Lawrence Erlbaum

[19] Grice, H. P. (1975). Logic and conversation, in Cole P. \& J. Morgan (eds.) Syntaxand Semantics 3: Speech Acts. New York: Academic Press, p. 75-89.

[20] Grundy, P. (2000). Doing Pragmatics. London: Arnold.

[21] L.Mey, J. (2001). Pragmatics : an introduction second edition. Australia: Blackwell Publishing.

[22] Sugiyono, P. D. (2018). Metode Penelitian Kuantitatif, Kualitatif, dan $R \& D$. Bandung: CV. Alfabeta.

[23] Webster, J. J. (1983). Some Sociolinguistic Aspects of Religious Communication. Ann Arbor, Michigan: University of Microfilms International.

[24] Dan Wang, Yudan.C, Jonathan R.H. Tudge. 2015. Expressions of Gratitude in Children and Adolescents: Insights From China and The United States. Journal of Cross-Cultural Psychology, 10.1177, 1-20

[25] Cüneyt Demir1 \& Mehmet Takkaç2. 2016. Contrastive Pragmatics: Apologies \& Thanks in English and Italian. International Journal of English Linguistics, 6, 1, 73-85

[26] Wafaa Daham Mohammed. 2020. A Comparative Socio-Pragmatic Study of thanking Patterns in English- Arabic Political Texts with Reference to Translation. Journal of Tikrit University for Humanities, 6, 27, 22-40

[27] Nisreen Naji Al-Khawaldeh, Vladimir Zegarac. 2013. Gender and the Communication of Gratitude in Jordan. Open Journal of Modern Linguistics, 3, 3, 268-287

[28] Chiayee Khorsheed Faqe1, Salah Jameel Jbrael2, Kovan Rzgar Muhammad3. 2019. The Use of Thanking Speech Act Strategies in English Realized by Kurdish EFL Learners at
Soran University. The Asian Institute of Research, 2, 3, 640-650

[29] Nisrin A. Hariri. 2016. Thanking in Saudi Academic Emails. Life Science Journal, 5, 13, 60-72

[30] Jiming Zhou, Yongyan Zheng \& Joanna HongMeng Tai. 2019. Grudges and Gratitude: The Social-Affective Impacts of Peer Assesment. Assesment and Evaluation in Higher Education (Routledge), 10.1080, 1-14 